\title{
Effect of Silica Fume as Partial Replacement of Cement on Compressive Strength of Roller Compacting Concrete
}

\author{
Israr Ahmed*, Aneel Kumar, Samar Hussain Rizvi, Mohsin Ali, Sabir Ali \\ Department of Civil Engineering, MUET, Jamshoro \\ ${ }^{*}$ Corresponding author: asrarahmed753@gmail.com
}

Abstract

Silica fume is an industrial by-product that can be used as a partial replacement of cement to enhance the strength related properties of roller compacting concrete. In past, industrial wastes were used to dump on earth, river, and sea that creates a hazardous environment for aquatic life as well as for humans. Nowadays, the use of industrial by-products as cement replacement is popular in the construction industry because it protects the environment from hazards. In this research, the effect of silica fume as partial replacement of sulphate resisting cement is investigated on the compressive strength of roller compacting concrete. Total four types of mix proportions were casted using concert mix ratio as 1:2:4 to investigate the compressive strength of roller compacting concrete at 7 and 28 days of curing age. The sulphate resisting cement was partially replaced with silica fume by $0 \%, 5 \%, 10 \%$, and $15 \%$ by weight of cement. The zero slump was maintained in all mixes. It was observed that the mix proportions containing $5 \%$ and $15 \%$ silica fume replacement showed maximum and minimum compressive strength of roller compacting concrete respectively.

Keywords-Roller compacting concrete, zero slump, compressive strength, silica fume, supplementary cementations material

\section{Introduction}

$\mathrm{C}$ ONSTRUCTION industry plays a vital role in the development of any country and region. Concrete is considered as the second most consuming material in the globe after water [1]. It is a man-made material that comprises of fine aggregate, coarse aggregate, cement, and water. Sometimes, it also contains admixtures based upon desired properties in concrete. At present, Pakistan produces 49.4 million tons of cement annually [2]. Cement is the main binding constitute in concrete. Worldwide, the annual production of cement in 2016 was 4.65 billion tons per year [3]. It is a well-known fact that around $7000 \mathrm{MJ}$ electrical power energy is required to produce one tone of cement and it releases the same amount of $\mathrm{CO}_{2}$ in the environment [4]. The production of a huge amount of $\mathrm{CO}_{2}$ and other greenhouse gases gives rise to a great environmental concern. To compensate this problem, many researchers are engaged to find the alternate of cement

ISSN: 2523-0379 (Online), ISSN: 1605-8607 (Print)

DOI: 10.52584/QRJ.1802.21

This is an open access article published by Quaid-e-Awam University of Engineering Science \& Technology, Nawabshah, Pakistan under CC BY 4.0 International License. which should be environment-friendly and has similar properties like cement.

The worldwide production of silica fume is estimated to be 1.5 million tons [5]. There is a big problem to dump massive waste amount which can create a danger to the environment and loss of land. The focus of this research is to partially replace ordinary Portland cement with silica fume to study the strengthrelated properties of roller-compacted concrete (RCC). $\mathrm{RCC}$ is the same as conventional concrete, but in this type of concrete, the compaction is done by a vibrating roller. The RCC is a dried mix having nearly zero slump mixture. To make it workable, water reducer and retarder chemical admixtures are used. This research attempts to produce RCC which will have properties such as low heat of hydration, economical, least thermal cracking, less permeability, high strength, durability, speedy construction, good performance, and lower maintenance cost. The RCC is used in dam construction and its rehabilitation, parking lots, ports, storage yards, shoulders, local streets, and high-speed pavements.

Ahmed et. al. [6] studied the mechanical properties 
of fly ash (FA) and silica fume replaced by cement in concrete. They replaced OPC cement with SF at $2.5 \%, 5 \%, 7.5 \%, 10 \%, 15 \%, 20 \%$. FA was replaced at $5 \%, 10 \%, 15 \%, 20 \%, 25 \%$ and $30 \%$. They concluded that at $10 \%$ of $\mathrm{FA}$ and $7.5 \% \mathrm{SF}$, the replacement showed the highest compressive strength $(65 \mathrm{~N} / \mathrm{mm} 2)$, split tensile strength $(5.2 \mathrm{~N} / \mathrm{mm} 2)$, and flexural tensile strength $(10.2 \mathrm{~N} / \mathrm{mm} 2)$, and minimum permeability.

Ramyar et. al. [7] conducted experimental studies on compressive strength, dry density, thermal conductivity and water absorption of concrete in which cement is replaced with FA and SF at $0 \%, 10 \%$, and $20 \%$ by weight of Portland cement with three foam content with $0 \%, 31 \%$ and $47 \%$ volume. They concluded that the mix with $1320 \mathrm{~kg} / \mathrm{m}^{3}$ dry density is the balanced benefit in terms of compressive strength and water absorption. A mix that has a high volume of foam content and SF showed the maximum compressive strength and showed the highest compressive strength over thermal conductivity ratio than the addition of FA.

Pattusamy et. al. [8] investigated the mechanical properties of concrete in which Portland cement was partially replaced with SF. They concluded that split tensile strength and compressive strength increases with the increase in SF content. Compressive and split tensile strength was maximum at $10 \%$ SF replacement, after which a decrease in strength occurred. Compressive strength and split tensile strength with $5 \% \mathrm{SF}$ replacement at 7 curing days are $19.34 \mathrm{~N} / \mathrm{mm}^{2}, 2.84$ $\mathrm{N} / \mathrm{mm}^{2}$. At 28 curing days both the factors are found to be $31.44 \mathrm{~N} / \mathrm{mm}^{2}, 4.75 \mathrm{~N} / \mathrm{mm}^{2}$. With $10 \% \mathrm{SF}$ at 7 curing days are $21 \mathrm{~N} / \mathrm{mm} 2,3.95 \mathrm{~N} / \mathrm{mm} 2$ and at 28 curing days are $34.93 \mathrm{~N} / \mathrm{mm} 2,4.92 \mathrm{~N} / \mathrm{mm} 2$. With $15 \%$ $\mathrm{SF}$ at 7 curing days, these factors are $18.3 \mathrm{~N} / \mathrm{mm}^{2}$ and $3.45 \mathrm{~N} / \mathrm{mm}^{2}$. At 28 curing days, the values are 30.20 $\mathrm{N} / \mathrm{mm}^{2}$ and $4.65 \mathrm{~N} / \mathrm{mm}^{2}$.

\section{Materials \& Methodology}

The sulphate resisting cement (SRC) was used for all concrete mixes. The reason to use SRC in roller compacting concrete is that it is used in the construction of highways and dam construction, where the possibility of sulphate attack is maximum. In this research work, SRC was obtained from the DG cement factory conforming to the ASTM standards. Silica fume is the by-product of silicon and ferrosilicon. The particle size of silica fume is approximately less than $1 \mu \mathrm{m}$. Silica fume was obtained from AlFalah Chemicals, Karachi, conforming to the ASTM standard [11]. The chemical composition of sulphate resisting cement and silica fume are shown in Table 1

\begin{tabular}{|l|l|}
\hline Chemical Composition & SRC (\%) \\
\hline $\mathrm{SiO} 2$ & 22.25 \\
\hline $\mathrm{Al} 2 \mathrm{O} 3$ & 4.21 \\
\hline $\mathrm{Fe} 2 \mathrm{O} 3$ & 4.88 \\
\hline $\mathrm{CaO}$ & 64.27 \\
\hline $\mathrm{MgO}$ & 0.92 \\
\hline $\mathrm{Na} 2 \mathrm{O}$ & 0.21 \\
\hline $\mathrm{SO} 3$ & 2.38 \\
\hline $\mathrm{K} 2 \mathrm{O}$ & 0.56 \\
\hline
\end{tabular}

TABLE 1: Chemical composition of SRC

\begin{tabular}{|l|l|}
\hline Chemical Composition & Silica Fume (\%) \\
\hline $\mathrm{SiO} 2$ & 88.17 \\
\hline $\mathrm{Al} 2 \mathrm{O} 3$ & 1.3 \\
\hline $\mathrm{Fe} 2 \mathrm{O} 3$ & 4.74 \\
\hline $\mathrm{CaO}$ & 0.50 \\
\hline $\mathrm{MgO}$ & 2.14 \\
\hline $\mathrm{LOI}$ & 2.3 \\
\hline $\mathrm{SiO} 2+\mathrm{Al} 2 \mathrm{O} 3+\mathrm{Fe} 2 \mathrm{O} 3$ & 96.85 \\
\hline
\end{tabular}

TABLE 2: Chemical composition of silica fume

and Table 2, respectively. The sand was collected from Bholary Quarry, Jamshoro, Sindh, having a specific gravity of 2.63. Coarse aggregate was collected from Nooriabad, Sindh, having a specific gravity of 2.612 . The maximum size of course aggregate used in this research was $20 \mathrm{~mm}$.

Before mixing, the aggregates were washed and dried properly. The properties of fine and coarse aggregates are mentioned in Table 3. Silica fume was replaced in a proportion of $0 \%, 5 \%, 10 \%$, and $15 \%$ by weight of the cement. A nominal mix proportion of 1:2:4 was used. The compaction of RCC was done by vibrating table and $9 \mathrm{~kg}$ surcharge on mold without any segregation occurrence. Over-compaction is avoided so that the segregation of concrete is prevented. During the whole lab work, the room temperature was in the range from 25 to 30 degrees Celsius. Roller compacting concrete is prepared according to the standards specified in [12]. The RCC mix proportions are shown in Table 4.

\section{Results \& Discussion}

Following sections describe the results of this study.

\begin{tabular}{|l|l|l|}
\hline Material & Property & $\begin{array}{l}\text { Relevant } \\
\text { standard }\end{array}$ \\
\hline $\begin{array}{l}\text { Fine } \\
\text { aggregate }\end{array}$ & $\begin{array}{l}\text { Specific gravity: 2.63 } \\
\text { Water Absorption: } 1.32\end{array}$ & $\begin{array}{l}\text { ASTM C128 }[9] \\
\text { ASTM C128 }\end{array}$ \\
\hline $\begin{array}{l}\text { Course } \\
\text { aggregate }\end{array}$ & Specific gravity: 2.612 & ASTM C127 [10] \\
Water Absorption: 0.69 & ASTM C127 \\
\hline
\end{tabular}

TABLE 3: Properties of coarse and fine aggregate 


\begin{tabular}{|c|c|c|c|c|c|c|c|c|c|}
\hline \multirow{2}{*}{$\begin{array}{l}\text { Mix } \\
\text { Proportion }\end{array}$} & \multicolumn{2}{|c|}{$\begin{array}{l}\text { Binder content } \\
\text { in } \%\end{array}$} & \multirow{2}{*}{$\begin{array}{l}\text { F. \& C. } \\
\text { Aggregate }\end{array}$} & \multirow{2}{*}{$\begin{array}{l}\text { W/B } \\
\text { Ratio }\end{array}$} & \multicolumn{5}{|c|}{ Amount of quantities in $\mathrm{Kg}$} \\
\hline & $\begin{array}{l}\text { in \% } \\
\text { SF }\end{array}$ & OPC & & & SF & OPC & F.Aggregate & C.Aggregate & Water \\
\hline $\mathrm{CM}$ & 0 & 100 & $\% \quad 100$ & 0.50 & 0 & 317 & 634 & 1268 & 158.5 \\
\hline SF5\% & 5 & 95 & 100 & 0.49 & 16 & 301 & 634 & 1268 & 155.33 \\
\hline SF $10 \%$ & 10 & 90 & 100 & 0.48 & 32 & 285 & 634 & 1268 & 152.16 \\
\hline SF $15 \%$ & 15 & 85 & 100 & 0.47 & 48 & 269 & 634 & 1268 & 149 \\
\hline
\end{tabular}

TABLE 4: Mix proportion required for $1 \mathrm{~m}^{3}$ of concrete

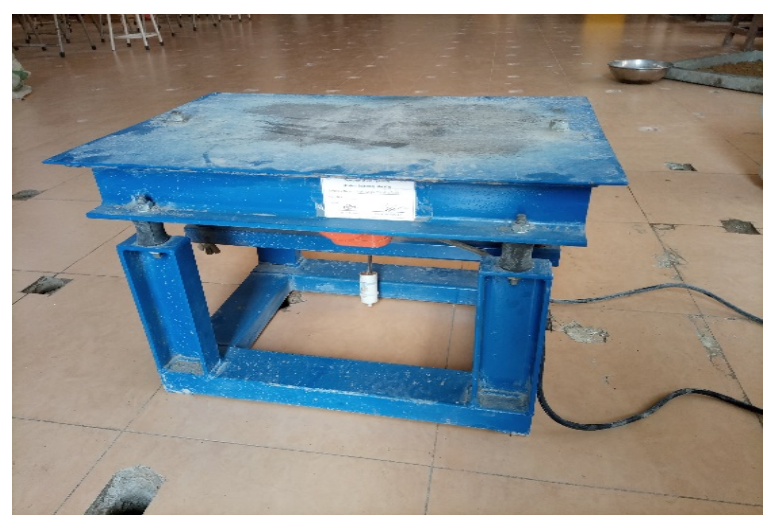

Fig. 1: Vibrating table

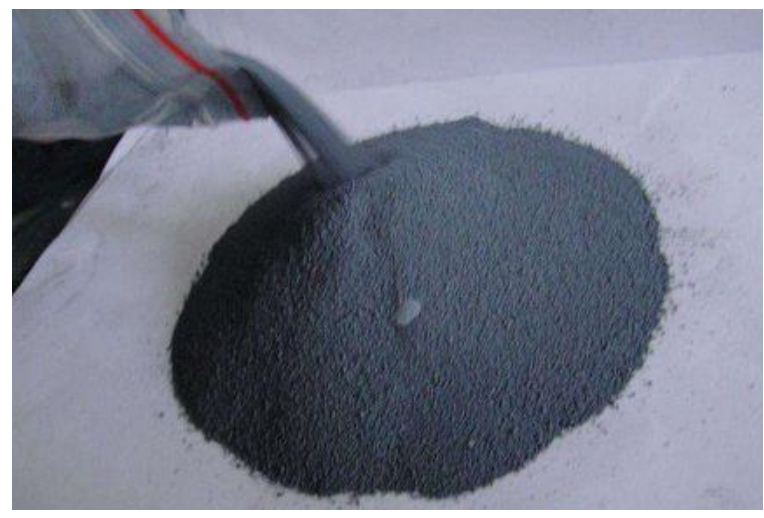

Fig. 2: Silica fume

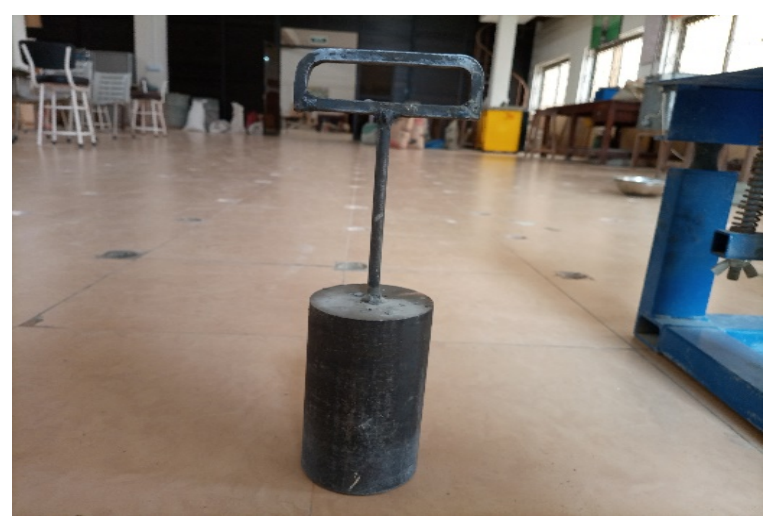

Fig. 3: 9 kg surcharge

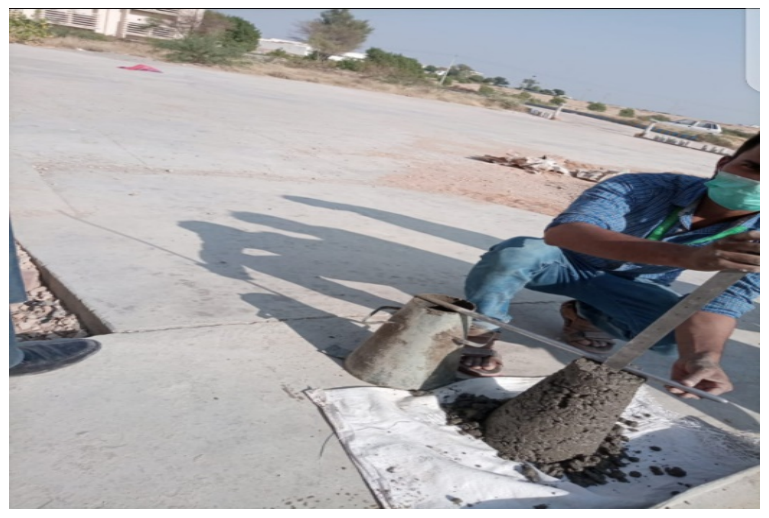

Fig. 4: Zero slump concrete

\subsection{Compressive Strength}

Compressive strength is one of the most important and very useful properties of materials and it was determined on cylindrical specimens. The size of the cylinder was kept as $100 \times 200 \mathrm{~mm}$ according to ASTM standards. Compaction was done in three layers. Each layer was filled with concrete up to the one-third height of mold and compacted by a vibrating table have a surcharge of $9 \mathrm{~kg}$ on mold. The RCC specimens were removed from molds after 24 hours and cured in potable water for 7 and 28 days. The compressive strength of RCC was determined at 7 and 28 days. Each mix had 6 specimens with 3 specimens for each curing age. Average strengths of 3 specimens are given in Table 5. Figure 5-6 show the behavior of RCC containing proportions of silica fume at different curing ages. At 7 days of curing, the compressive strength of $\mathrm{RCC}$ is increased at $30.36 \mathrm{MPa}$ by substituting $5 \%$ of silica fume. The compressive strength of controlled concrete at 7 days was recorded as $15.61 \mathrm{MPa}$, which is approximately half of the strength achieved by utilizing $5 \%$ silica fume. The $10 \%$ substitution of silica fume showed the compressive strength of $28.29 \mathrm{MPa}$, which is slightly less than that of $5 \%$ replacement. The utilization of $15 \%$ silica fume in RCC showed an increase in compressive strength, but it was smaller compared to $5 \%$ and $10 \%$ replacement levels. At 28 days curing period, the compressive strength of $5 \%$ SF replacement was recorded to be $32.12 \mathrm{MPa}$ which 


\begin{tabular}{|c|c|c|c|}
\hline \multirow{2}{*}{ No. } & \multirow{2}{*}{ Mix } & \multicolumn{2}{|c|}{$\begin{array}{c}\text { Average Compressive } \\
\text { Strength (MPa) }\end{array}$} \\
\cline { 3 - 4 } & & 7 days & $\mathbf{2 8}$ days \\
\hline 1 & $0 \% \mathrm{SF}$ & 15.613 & 29.461 \\
\hline 2 & $5 \% \mathrm{SF}$ & 30.361 & 32.121 \\
\hline 3 & $10 \% \mathrm{SF}$ & 28.29 & 31.551 \\
\hline 4 & $15 \% \mathrm{SF}$ & 26.715 & 30.173 \\
\hline
\end{tabular}

TABLE 5: Average compressive strength of cylinders

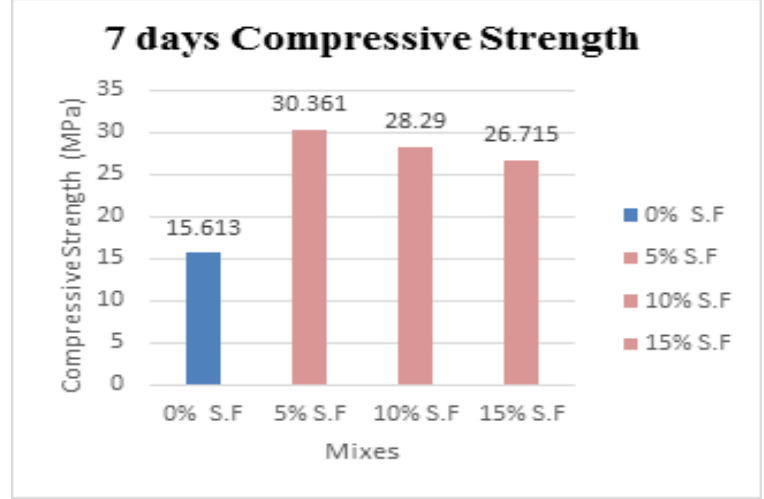

Fig. 5: Compressive strength of cylinders for 7 days

is again higher than the controlled concrete. At $10 \%$ and $15 \%$ replacement, the roller compacting concrete showed higher strength at 28 days.

$$
\text { Strength activity index }=\frac{A}{B} \times 100
$$

where $A$ is the strength of concrete with blended cement, and $B$ is the strength of concrete with OPC. The behavior of compressive strength is shown in Figure 9. The addition of $5 \%$ silica fume replacement with cement showed a higher compressive strength compared to the controlled mix. With the increment in the proportions of silica fume, the compressive strength continuously decreased. Figure 9 shows that the variation of percentage of silica fume increases the compressive strength first, and then decreases after $5 \%$

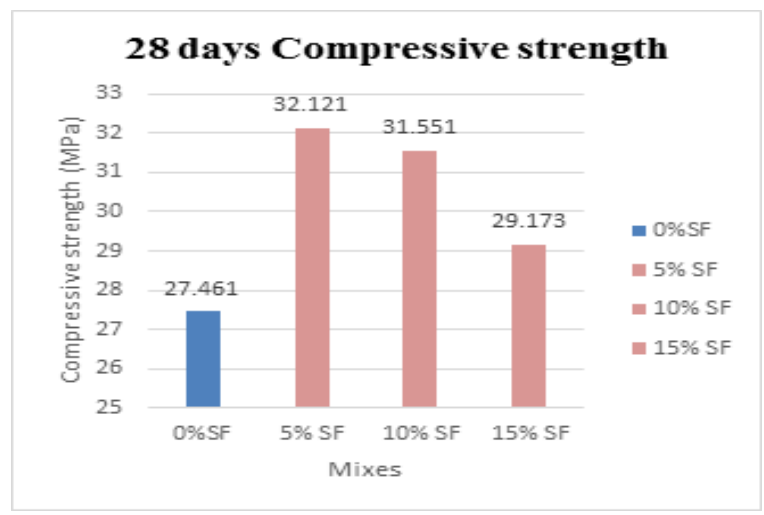

Fig. 6: Compressive strength of cylinders for 7 days

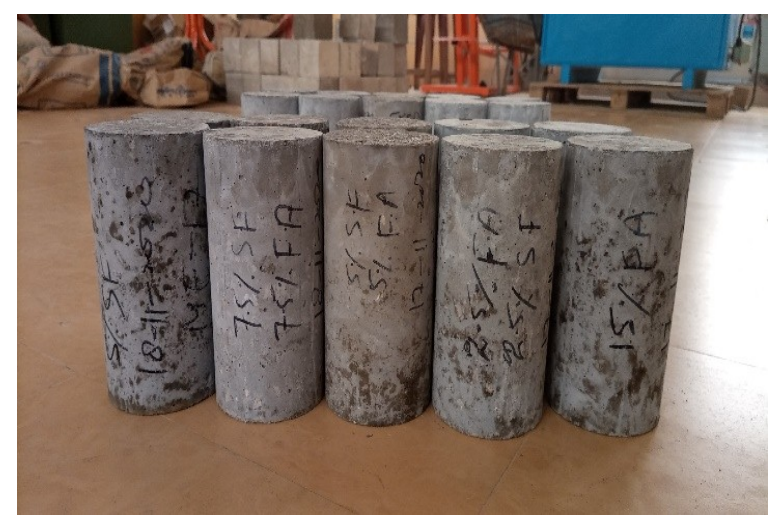

Fig. 7: Concrete cylinders

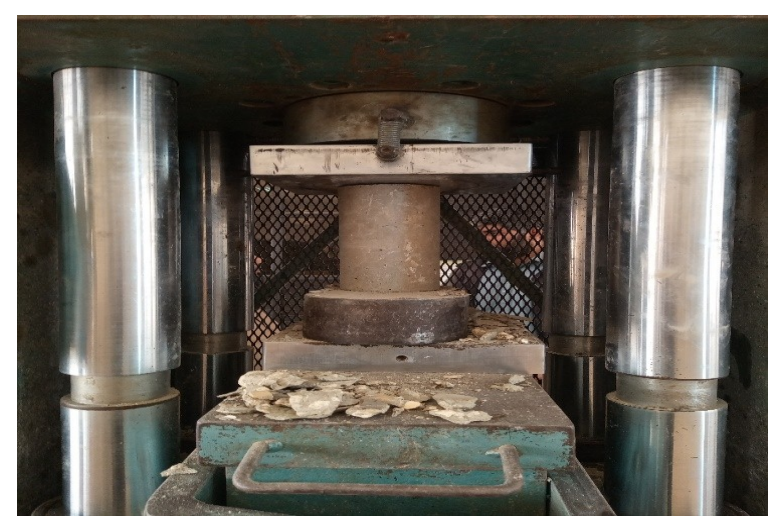

Fig. 8: Compressive strength test

of silica fume. Strength activity graph shows that the variation of percentage of silica fume increases compressive strength up to $5 \%$ of silica fume replacement, and a further increase in silica fume percentage decreases the compressive strengths of roller compacting concrete. It can be seen that the partial replacement of cement with silica fume has a positive impact on the compressive strength of roller compacting concrete. At $5 \%$ substitution of silica fume, the strength activity

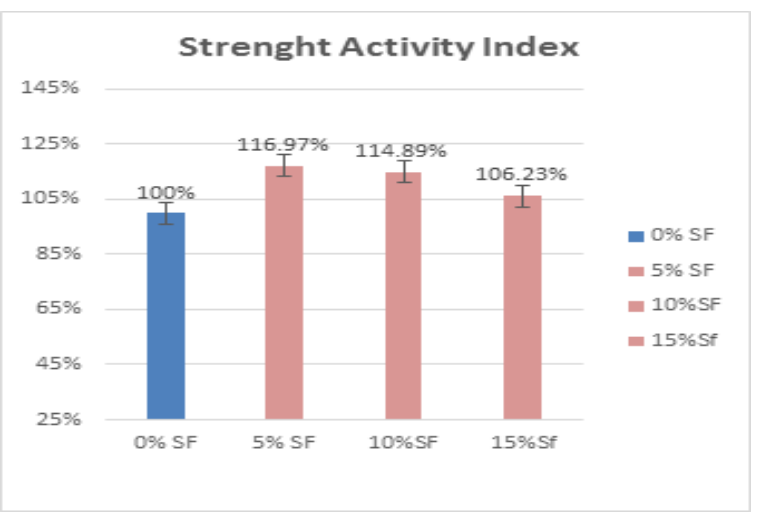

Fig. 9: Strength activity index of silica fume with control mix of Roller compacting concrete 
index was calculated as $116.97 \%$ which is $16 \%$ higher than the controlled mix.

\subsection{Conclusion}

The following conclusions are drawn based on our experimental study.

- Due to the pozzolanic property of silica fume, the compressive strength of roller compacting concrete significantly increased.

- The higher compressive strength of roller compacting concrete was noted to be $32.121 \mathrm{MPa}$ by utilizing $5 \%$ silica fume with sulphate resisting cement. Further increase in the replacement proportion resulted in a decrease in the compressive strength of roller compacting concrete.

- After 5\% replacement, the further increment of replacement proportion decreased the compressive strength. The lowest compressive strength of RCC was recorded to be $30.17 \mathrm{MPa}$ by substituting $15 \%$ replacement of silica fume with sulphate resisting cement.

Based on the outcome of the research presented in this paper, following suggestions for the future work are given.

- Other dosage of silica fume may be used.

- Tensile strength of roller compacting concrete may be checked.

\section{Acknowledgement}

The author wish to thank Civil Engineering Department, MUET, Jamshoro for providing every type of support to conduct this research.

\section{References}

[1] N. Tosic, S. Marinkovic, and A. Stojanovic, "Sustainability of the concrete industry: Current trends and future outlook," Tehnika, vol. 72, no. 1, pp. 38-44, 2017.

[2] C. Financials, "The State of Pakistan's Economy - Third Quarterly Report 2017 - 2018 - Special Section - 1."

[3] Cembureau, "2017 Activity Report," 2017.

[4] B. S. C. Kumar, V. K. Varanasi, and P. Saha, "Sustainable Development Using Supplementary Cementitious Materials and Recycled Aggregate," 2012.

[5] H. Patil, "Study and Optimization of Silica Fume in Concrete," Int. J. Recent Trends Eng. Res., vol. 3, no. 5, pp. 562-565, 2017.

[6] M. M. A. and M. T. R. B. Muhit, S. S. Ahmed, I. B. Muhit, S. S. Ahmed, M. M. Amin, and M. T. Raihan, "Effects of Silica Fume and Fly Ash as Partial Replacement of Cement on Water Permeability and Strength of High Performance Concrete," Aetace 2013, pp. 108-115, 2013.

[7] H. S. Gökçe, D. Hatungimana, and K. Ramyar, "Effect of fly ash and silica fume on hardened properties of foam concrete," Constr. Build. Mater., vol. 194, pp. 1-11, 2019.
[8] V. Pattusamy, N. Nandini, M. Vijay, and K. Bheemappa, "Formulation and Evaluation of Mouth Dissolving Tablets of Antibacterial Agent," Int. J. Adv. Res., vol. 1, no. 6, pp. 77-82, 2013.

[9] C. Ag-, B. Statements, and W. Pycnometer, "Standard Test Method for Relative Density ( Specific Gravity ) and Absorption of Fine," vol. i, pp. 2-7, 2019.

[10] C. Ag- and B. Statements, "Standard Test Method for Relative Density ( Specific Gravity ) and Absorption of Coarse," pp. 1-5, 2020.

[11] Astm, "Standard Specification for Coal Fly Ash and Raw or Calcined Natural Pozzolan for Use," Annu. B. ASTM Stand., no. C, pp. 3-6, 2010.

[12] C. C. Test, C. C. Test, T. C. Vertically, and C. C. Specimens, "Standard Practice for Making Roller-Compacted Concrete in Cylinder Molds Using a Vibrating Table 1," pp. $1-5,2019$. 